I Universidade Federal Fluminense (UFF), Niterói, RJ, Brasil

silviano.santiago@gmail.com

Silviano Santiago'

\title{
A MODA COMO METÁFORA DO CONTEMPORÂNEO
}

\author{
"Proletários, uni-vos". Isto era escrito sem vírgula e sem traço, \\ a piche [no muro]. [...] Aquela maneira de escrever comendo os sinais \\ indignou-me. Não dispenso as vírgulas e os traços. Quereriam fazer \\ uma revolução sem vírgulas e sem traços? Numa revolução de tal \\ ordem não haveria lugar para mim. Mas então. \\ (Graciliano Ramos, Angústia)
}

\section{A MODA: POLO POSITIVO/POLO NEGATIVO}

Moda é acontecimento fantástico e terrível. A etimologia de um e do outro adjetivo nos estimula. Fantástico, do grego phantastikós, tem a ver com a produção da imaginação do indivíduo, associada à fantasia pessoal. Terrível, do latim terror, tem a ver com a descrição dum clima geral de espanto, horror e pavor. A moda é o contemporâneo, insinua Nietzsche em definição paradoxal que está nas Considerações intempestivas e é retomada por Giorgio Agamben (2009) em curto ensaio, hoje célebre. Afirma Agamben (2009: 58-59) que o contemporâneo não é o presente, é o inatual, ou seja, ele é aquilo que se localiza fora do espaço e fora do tempo, entregue ao ser humano pelas circunstâncias.

Retomo a frase inicial para alongá-la. Moda é metáfora para o acontecimento fantástico e terrível, fora do espaço e do tempo, propiciado pelas circunstâncias àquele que deseja pensar o seu tempo na qualidade de contemporâneo. O ser humano inteligente e criativo insere a si como contemporâneo sob a forma de acontecimento, dramatização ou reflexão, que se espetaculariza em espaço deslocado daquele em que vive e em tempo anacrônico. Dessa forma, o contemporâneo se robustece com competência e se engrandece com força crítica, suficientes para melhor compreender - em atitude e comportamento paradoxais, repita-se - os desacertos e desconcertos da sua época. Alerta Agamben (2009: 59): a não coincidência entre situação e atualidade não é instaurada 
para que o homem se refugie noutra cidade e noutro século. Tampouco é instaurada para que ele seja um nostálgico, a sentir-se mais em casa na Atenas de Péricles ou na Paris de Robespierre. O ser humano inteligente e criativo sabe que não pode furtar-se ao seu tempo.

A lógica exemplar do desfile de moda feminina oferece a Agamben um mirante metafórico, de que ele lança mão para legitimar o modo como o contemporâneo não se cola à sua época, reproduzindo-a. Ele se adianta a ela para manter ou para fomentar um diálogo mais ambicioso sobre a atualidade. $\mathrm{Na}$ passarela, a bela e intempestiva roupa da moda oscila entre o momento-quejá-não-é-mais e aquele cujo presente-ainda-não-chegou, e que, na melhor das hipóteses, estaria para chegar. O desfile de moda é reconhecido como acontecimento de algo que ainda não é e que talvez seja algum dia. "Neste instante estou na moda" - a afirmativa só faz sentido se dita por Gisele Bündchen ao desfilar na passarela.

Se a mesma frase for dita pela modelo a caminhar ao lado do marido, Tom Brady, e filhos pelas ruas de Nova York, ela não é intempestiva nem paradoxal. É apenas a fala vazia duma supermodel autoirônica e fanfarrona, contraditória e nostálgica. Dissera ao paparazzi uma frase típica de rainha da cocada preta, e como as há nestes anos que gostam de oferecer - metafórica e equivocadamente - o reality show ou o talk show televisivo como signos da contemporaneidade. Nada é menos contemporâneo do que o comportamento ou a fala de Donald Trump em campanha política que lembra o reality show em que foi ator canastrão.

O espaço e o tempo da bela e intempestiva roupa da moda (em desfile pela passarela) são o espaço e o tempo próprios à contemporaneidade e se bifurcam em um "não mais, já chega" (passado) e um "espera, ainda não" (futuro). Ancoram-se entre as duas situações: entre a rejeição do passado e a atitude de espera, com vistas à configuração do futuro. Tanto o filme Barbarella (I968), dirigido por Roger Vadim e interpretado por Jane Fonda, quanto Esperando Godot (I948) e Fim de jogo (I957), peças de Samuel Beckett, servem de boa metáfora para a discussão sobre contemporaneidade.

A moda é, pois, mistura explosiva. Nas discussões canônicas sobre contemporaneidade pouco se acentua o fato de que a moda pode apontar para um polo positivo e, ao mesmo tempo, para um polo negativo do desempenho e da criação humanos no cotidiano. Um acontecimento-de-moda (Gisele na passarela) é contemporâneo, e o acontecimento-em-moda (Gisele a caminhar pelas ruas) não o é. O acontecimento-em-moda representa o polo negativo da metáfora usada originalmente por Agamben. O acontecimento-em-moda é espetáculo que se deixa seduzir pela luminosidade e pelo encanto oferecido ao espectador pelo presente. Mesmo se vista da perspectiva do seu polo negativo, a moda, embora não enxergue o contemporâneo e não sendo, portanto, metáfora positiva dele, é também produto, embora degradado, da imaginação associada à fantasia pessoal. 
A diferença entre o polo positivo e o polo negativo da metáfora reside no fato de que, se seduzida pela luminosidade e pelo encanto do presente, a moda se manifesta como oportunista e, por ricochete, narcisista, à semelhança de todo e qualquer acontecimento de responsabilidade de entrepreneur ${ }^{\mathrm{I}}$ que se preze nas atuais sociedades capitalistas. Embora o acontecimento-em-moda seja um produto fantástico, ele não é terrível, isto é, não descreve o clima geral de espanto, horror e pavor que recobre a atualidade. ${ }^{2}$ Acrescente-se em contraste que, do ponto de vista do polo positivo, o acontecimento contemporâneo moda é a única migalha da produção de utopia que os inglórios fados da atualidade mundial têm-nos oferecido desde o fim da Segunda Guerra Mundial.

Reabro, pois, a metáfora inicial da moda pelo polo negativo. Reabro-a com exemplo, pela menção silenciosa às várias profissões-em-moda no mundo capitalista, que oscilam entre a atriz e o ator televisivo e o cirurgião plástico. Reabro-a pelas profissões-em-moda para ir além do campo estreito e positivo em que a situamos - a passarela - a fim de melhor compreender as caracterís ticas do polo negativo da moda. Na passarela, fica claro, só atuam com exclusividade os profissionais da moda, o/a "fashionista" e o/a modelo. Já o entrepreneur - não importa a profissão-em-moda que o/a qualifique - almeja exibir-se à sua época pelo sucesso alcançado e pelo rápido enriquecimento individual. Ragged to riches stories, no melhor estilo da tragédia americana dramatizada por Horatio Alger ou pelo filme Um lugar ao sol (I95I), de George Stevens, refilmado por Woody Allen como Match point (2005).

O oportunismo e o narcisismo são decorrência da opção do sujeito pelo polo negativo da moda. O sujeito não é moda, ele está-na-moda ou fica-em moda. Ao se querer figura pública reconhecida pelo trabalho pragmático, o empreendedor acha melhor - se tiver de decidir entre enriquecimento e sucesso - ficar com os dois para estar realmente na moda neoliberal. Ao se transformar em modo de comportamento e expressão típicos de sociedade capitalista, a moda deixa a fantasia-profissional-liberal-de-sucesso fluir com o apoio da imaginação fértil e abundante a fim de que as chamas da riqueza e da fama se realimentem em época em que o clima geral de espanto, de horror e de pavor tomba sobre a nação e a terra e toma todos, indistintamente.

Agamben (2009: 62-63) apenas acentua o polo positivo da moda. Copio-o: “Todos os tempos são, para quem deles experimenta contemporaneidade, obscuros. Contemporâneo é, justamente, aquele que sabe ver essa obscuridade, que é capaz de escrever mergulhando a pena nas trevas do presente".

Tento aquecer a discussão, repetindo-me. Polo positivo da metáfora da moda: levar o sujeito a ver a obscuridade, mergulhando a pena nas trevas do presente. Polo negativo da metáfora da moda: levar o sujeito a se deixar seduzir pelas luzes do presente, a fim de que se concretize o desejo individual e intransferível de enriquecimento e de fama. 
O contemporâneo é, pois, o sujeito que se descola do presente em que vive para perceber o escuro da atualidade em que vivemos todos. Com o auxílio dos neurofisiologistas Agamben (2009: 63) alerta para o fato de que a percepção do escuro do presente não é manifestação de inércia ou de passividade por parte do observador. Implica entregar-se à atividade - ao trabalho fora do espaço do presente e fora do tempo que lhe toca viver - de neutralizar as luzes sedutoras que provêm da época para enxergar suas trevas, de que são inseparáveis.

Contemporâneo é só quem recebe no rosto o facho de trevas - e não de luzes - que provém do seu tempo. Recebe o facho de trevas no rosto e, no entanto, enxerga.

A metáfora da escuridão do tempo presente é também explicada por Agamben (2009: 64-65) pelo recurso à compreensão da escuridão das constelações no céu. As galáxias mais remotas se distanciam de nós a uma velocidade tão absurda, que sua luz não consegue nos alcançar. Aquilo que percebemos como o escuro do céu é essa luz a viajar velocíssima até nós sem nunca chegar a alcançar-nos, porque as galáxias das quais a luminosidade provém se distanciam a uma velocidade superior à da própria luz.

\section{O LIVRO-EM-MODA: O BEST-SELLER}

Tomada de Giorgio Agamben e acrescida de nota de minha responsabilidade, essa reflexão apressada sobre o contemporâneo (ou sobre a moda como metáfora privilegiada do contemporâneo) introduz a análise a que me proponho: estudar a questão do privado e do público da perspectiva da produção editorial que vai do final do século XX ao começo do século XXI. Não há como não encarar o tema proposto, a não ser pelo polo negativo em que a metáfora da moda se apresenta. Repito. Polo negativo da moda. Levar o sujeito a se deixar seduzir pelas luzes do presente, a fim de que se concretize seu desejo individual e intransferível de enriquecimento e de fama. Faz-se de conta (make believe) que se enxerga a obscuridade. Faz-se de conta que se a enxerga porque as luzes fortes e sedutoras que iluminam a época não foram prévia e devidamente neutralizadas pelo observador. No escritório ou consultório empresarial, o empreendedor opta por não receber o facho de trevas no rosto. Está cego pelo excesso de luzes.

Pelo fato de o objeto deste texto homenagear - e, ao mesmo tempo, furtar-se a - Agamben e querer observar o acontecimento da moda pelo seu polo negativo, proponho dois aditamentos à questão geral proposta, aditamentos esses que julgo poderão ser dignos de tratamento original, ou pelo menos atrevido, por parte de quem vos fala. Com os aditamentos, eu não quero fugir pela tangente. Pelo contrário. Viso esclarecer minha dupla intenção de discutir as noções sociológicas em pauta (público e privado) a partir da perspectiva pouco explorada pelos analistas, ou seja, a da produção ou do mercado editorial.

Primeiro aditamento. Proponho-me a analisar como as noções tradicio- 
nais de privado e de público são acionadas nas últimas décadas pelos artistas ou pensadores dependentes do mercado editorial. Refiro-me, claro, a todo escritor que, tendo a carreira pública conduzida pela venda desmedida dos seus livros, recebe dos leitores a carteirinha de reconhecido autor de best-seller (ficcional ou ensaístico, não me interessa a distinção). Os autores de best-seller são recompensados, de imediato, pela boa recepção e pelo bom dinheiro dos leitores, e têm sucesso junto à sociedade letrada nacional e estrangeira e aos jornais e revistas, e, por efeito de eco na mídia televisiva, junto aos que não são letrados e podem até ser analfabetos. Estes não leem o livro, mas reconhecem a foto do autor pela fama que o acompanha.

Pelo segundo aditamento, levanto hipóteses sobre o modo como o livro bem aquinhoado pelo mercado editorial trabalha de modo negligente e otimista a mente do leitor que sobrevive em situação de pavor, de desespero ou de aflição. O leitor está a viver "tempos obscuros", para retomar Agamben, mas o autor de best-seller opta por não lhe oferecer o livro que ele precisa para receber no rosto o facho de trevas da contemporaneidade. Oferece-lhe o livro que lhe permite ser mais docilmente seduzido pelas luzes da atualidade. A fortuna pessoal e a fama do escritor advêm do fato de que o livro-em-moda, o best-seller, não habilita o leitor a neutralizar as luzes da contemporaneidade para que enxergue as trevas do presente. Autor, editora e livraria entregam às mãos do leitor um veículo do pensamento alheio, veículo de fácil manejo, dócil e perfeitamente adequado ao status quo.

Fecha-se o círculo: produção, comercialização, consumo. E divulgação gratuita. Os livros de sucesso junto ao grande público alfabetizado são respaldados pelas famosas listas de best-sellers da semana, que os tornam recomendáveis a todas e a todos.

Essas listas tiveram um curioso e fascinante desempenho e impacto nos últimos 40 anos da indústria e do comércio dos livros no Brasil e no estrangeiro, desempenho e impacto que devem ser devidamente circunscritos pelos dois aditamentos que encaminham a uma avaliação do discurso de best-seller. Ao se propor a colocar a nu as noções de privado e de público, os discursos ficcionais e ensaísticos vitoriosos - revestidos da forma livro - se propõem também a colocar a nu as duas noções em pauta a fim de que possam servir de apoio - se não exagero e não abuso de vossa tolerância - ao aparato político e/ou ideológico que lhes corresponde em análise do período histórico em que o cidadão brasileiro está para sair da ditadura militar implantada em I964 a fim de reinaugurar tempos democráticos. Refiro-me ao elogio duma política privada e pública a favor do consumo como caminho para a cidadania plena que se transforma em questão candente em tempos pós-ditatoriais que se desejam igualitários e democráticos.

Em se tratando básica e circunstancialmente de discurso por autor em direção a leitor, em se tratando, portanto, de diálogo virtual entre consciências 
individuais online (para emprestar ao ato de ler uma metáfora-em-moda), esclareço que as noções de privado e de público visitadas aqui trazem uma carga pesada de subjetividade, que não está isenta dos valores elitistas predominantes na história social do Brasil. Esclareço mais. Embora o diálogo entre autor e leitor seja virtual, já que delimitado pelo objeto silencioso chamado livro, em que o jogo da fala em reciprocidade só é delegado a poucos, ou seja, ao que é crítico, resenhista ou professor/a universitário/a, é também importante esclarecer que, em se tratando de livro escrito em linguagem dócil, fácil e perfeitamente manejável, a intersubjetividade em si - no caso do best-seller, reafirmo - se articula de modo pleonástico e é perfeitamente descartável por reflexão crítica que vise a resgatar o polo positivo da moda. Pela leitura a fala da intersubjetividade é comum à figura que escreve (autor) e à figura que lê (leitor), já que ambos repetem as mesmas palavras/ideias que, com o correr dos dias, se transformarão em chavões e em clichês de fácil circulação nas redes sociais.

As luzes do presente nunca são neutralizadas pelas luzes correspondentes do diálogo online entre o autor de best-seller e o seu leitor. O otimismo - o alto astral, para ficar com expressão que ganhou direito de cidadania nos trópicos graças à Xuxa - do autor participativo e do leitor participante, se não exagero, é a clave de dó do mercado editorial que alavanca o best-seller. Embora se divulgue que o best-seller se deixa enquadrar pelo esforço em democratizar a leitura, ele na verdade nem de longe toca o nó górdio da boa educação em massa, isto é, uma educação pública indiscriminada em termos de classe. A lista dos livros mais vendidos não afeta nem de longe o sistema educacional em vigor. (Como trilha musical mistificadora, recomendo aos mais jovens que ouçam a canção "Alto astral", na voz de Xuxa, ${ }^{3}$ ou lembrem o personagem hilário de Claudia Raia, Samantha Santana, cantando "Tô ôca, sabe".)4

\section{ELOGIO DO BEST-SELLER}

Todo mundo tá revendo o que nunca foi visto Todo mundo tá comprando os mais vendidos É qualquer nota, é qualquer notícia Páginas em branco, fotos coloridas

(“O papa é pop”, cantada pela banda Engenheiros do Hawaii, I99I).

Os dois aditamentos que propus à reflexão de Agamben sobre a moda - (a) o modo como o mercado editorial aciona as noções tradicionais de público e de privado e (b) o modo como o best-seller trabalha de maneira negligente e otimista a mente do leitor que está circunstancialmente em situação de desespero e de aflição - são prefigurados concretamente nos anos considerados de abertura no Brasil e ganharão forma fixa quando se aproximarem os anos I990. A última década do século XX se abre com a notável canção "O papa é pop", em epígrafe, cantada pela banda Engenheiros do Hawaii. Também naquela época 
os dois aditamentos não só ganham forma fixa como passam a se desdobrar em inesperada, estranha e notável coincidência, que será levantada ao final da nossa conversa. Começo pelo começo. Perdão pela nota de suspense hitchcockiano.

Acredito que Roberto Drummond, famoso contista ${ }^{5}$ mineiro, tenha sido o primeiro a fazer o elogio do best-seller no período histórico que se denomina, ainda que precariamente, abertura ou distensão, ou ainda pós-ditatorial.

$\mathrm{O}$ argumento de Roberto Drummond a favor de uma literatura jovem entre nós é crítico da então substantiva literatura underground (ou alternativa) no Brasil e na América Latina e, por essa razão, se reforça pela admiração ao tremendo sucesso internacional da música britânica dita pop, de que é exemplo o grupo dos Beatles. Em entrevista que abre a coleção de contos A morte de D. J. em Paris (I975), Roberto não subestima a ousadia da proposta. Afirma que ainda não consegue definir o que seria uma literatura pop porque "é um troço ${ }^{6}$ que tá começando, tá nascendo". Arrisca-se, em seguida, a propor a comparação atrevida como novo paradigma literário: “literatura 'pop' é um negócio capaz de fazer da literatura o que os Beatles fizeram na música - tornar a literatura um troço tão importante pra gente como esse cigarro que você tá fumando e que tá preenchendo um momento de sua vida; como um comprimido de AAS [aspirina] que você toma quando tá com dor de cabeça" (Drummond, I975: 3).

Ao delegar ao livro-em-condição-de-virar-pop a importância do efeito relaxante do cigarro num momento de descanso, ou ao emprestar-lhe as graças do alívio da dor de cabeça proporcionado pela ingestão duma aspirina, Roberto está dizendo que a leitura reduz a tensão psicológica, apazigua a mente estressada e tranquiliza o cotidiano vazio, dolorido e ensimesmado do cidadão comum. Este sai da leitura como um sujeito desoprimido, autogratificado e feliz. O livro é meu cigarro, dirá um; é minha aspirina, dirá outro. Ele é meu entretenimento, dirá um terceiro. Continua Roberto, agora definindo o objetivo abrangente da literatura pop: "Uma literatura que o menino aí do elevador, numa hora de folga, num feriado, possa pegar e ler e entender à maneira dele". Completa, anunciando o Caetano Veloso da canção "Gente" (I977): "Acho que a gente tem que ser estrela, tem que dar esperanças. Acho que o escritor tem que dar amparo, entende?" (Drummond, I975: 3, destaque meu).

Sob a influência da produção musical pop no Primeiro Mundo, a opção por acreditar que, no período pós-ditatorial brasileiro, o livro possa ser entretenimento em busca do sucesso de venda nas livrarias logo toma caminho em sentido oposto. O paradigma pop proposto no começo da entrevista passa a ser matizado pela atenção que o próprio Roberto Drummond presta à função empenhada da literatura brasileira, que sempre se reforçou pelo apelo à expressão do caráter nacionalista e/ou latino-americano na linguagem e na trama. O escritor pop não é gerado na sociedade da abundância europeia ou norte-americana. Vive num Brasil injusto e despedaçado, que é o avesso das benesses apregoadas pelo regime ditatorial militar. 
E a liberdade na interpretação do livro, concedida de graça ao menino do elevador (ele deve entender o livro à maneira dele), se transforma, contraditoriamente, em reivindicação de autoridade ou de autoritarismo por parte do autor. Este tem que dar "amparo" ao leitor. Ao ampará-lo na vida cotidiana, o autor tem também de ampará-lo no comportamento político. Roberto salienta, então, que os escritores brasileiros e latino-americanos não devem se submeter à moda de Londres ou de Nova York, já que - e o cito - "nós temos condição de ditar" (Drummond, I975: 3, destaque meu). A polissemia do verbo ditar por um escritor em tempos pós-ditatoriais não é simples. Menos simples se precedido de generosa concessão de liberdade ao menino semialfabetizado que deve usufruir dos prazeres da leitura.

A ambiguidade inicial do paradigma pop tem como consequência a situação de ditador concedida ao escritor, ou seja, o escritor que transforma a imitação da literatura estrangeira como forma dominante na literatura nacional em nuestra influência na literatura norte-americana. Não temos ditadores da literatura jovem no Brasil; daí que Roberto acabe por reconhecer como o único a merecer o mérito um reconhecido contista cosmopolita e conservador, Jorge Luis Borges. Por ditar a nova norma literária na literatura universal, Borges inverte a antiga condição colonial, imitativa, da nossa literatura. Cito Roberto a transformar Borges em exemplo pop: "É o que a literatura latino-americana tá fazendo, pois hoje você encontra [norte-] americano imitando Borges". O esquema inicial proposto, cujo paradigma é ditado pelo sucesso popular dos Beatles, é contraditoriamente invertido pela influência do sofisticado Borges no hemisfério norte, hemisfério povoado a partir de então por escritores nossos imitadores.

Moral: depois de ter apresentado despretensiosa e pretensiosamente o futuro pop da literatura no Brasil, Roberto tem de trabalhar a questão da língua e da trama nacionais. Para tal, invoca o nome de Manuel Bandeira (sem o mencionar) como alicerce duma literatura atual que se quer em-moda. Ao escutar o próximo argumento de Roberto, lembrem o poema "Evocação do Recife" (I 925): 7 "Pra mim, literatura é um negócio que tá acontecendo o tempo todo: tá acontecendo no barzinho aí embaixo, tá acontecendo dentro de um elevador com um cara que não estudou, com a garçonete que não é escritora. Então, o negócio é incorporar a linguagem desse pessoal, entende?" (Drummond, I975: 3). Uma afirmação tautológica arremata o argumento por um lado: "No Brasil, quem realmente faz a linguagem do povo é o próprio povo brasileiro". E outra afirmação, que questiona o livro que não ambiciona ser best-seller, o arremata pelo outro lado: "Eu não quero ser um intelectual. Eu prefiro que me acusem de ser um Zé Mauro de Vasconcelos, ${ }^{8}$ [...] mas que eu faça isso - uma literatura realmente popular". O autor de livro pop não é intelectual. Seu leitor não é o crítico, é quem o consome. Só importa que o livro publicado tenha a repercussão dos livros de José Mauro de Vasconcelos. Os consumidores de livro - em número absurdo para o até então minguado mercado editorial brasileiro - são 
o alicerce do paradigma pop proposto por Roberto e os verdadeiros avalistas/ avaliadores do best-seller.

Se a autogratificação proporcionada pela leitura é semelhante à que lhe é dada pelo cigarro ou pela aspirina, a participação política do leitor - o detalhe é importante em tempos pós-ditatoriais - será objeto de mais um raciocínio tautológico. O pensamento participativo do leitor pop comunga com o pensamento empenhado do autor pop. O livro desaparece ao assumir radicalmente o silêncio da escrita e apenas se expressa se instrumentalizado em público. Não falta a Roberto um bom exemplo. Retira-o de sua ida ao Colégio Santo Antônio e a conversa que mantém com os alunos da $8^{a}$ série (I4-I5 anos) que leem o famoso poema "José", de Carlos Drummond. Cito Roberto: "Uma molecada que você acha que não está com nada, começou a discutir problemas de liberdade, e o poema não fala a palavra liberdade, não fala em prisão" (Drummond, I975: 4).

Em seguida, Roberto observa um notável desvio na discussão entre os jovens. Transitam do poema de Carlos Drummond para uma canção de Chico Buarque. O jogo entre dois períodos difíceis por que passa a nação - a ditadura Vargas, anos 40, Drummond, e a ditadura militar, anos 60, Chico - reaparece curiosamente sob a bandeira da mistura da dicção culta com a popular (ou a pop). O poema e a canção da MPB se redefinem pela opção pop que alimenta a discussão dos jovens sobre política e desmonta, contraditoriamente, as homenagens iniciais prestadas ao prazer do cigarro, ao alívio da aspirina e a Jorge Luis Borges.

Na verdade, em tempos ainda ditatoriais não há momento de folga no cotidiano do leitor inteligente, e a vida só lhe traz dor de cabeça. Cito Roberto: "Acho que [a literatura pop] tem que ser uma literatura de briga e de luta, ainda que aparentemente ela não esteja demonstrando nada disso". Roberto aproveita o galeio proporcionado pelo jogo comparativo entre ditaduras e redesenha, contraditoriamente, o perfil multivalente do autor de livros de sucesso em tempos pós-ditatoriais: "O escritor tem de ser um marimbondo, um Chacrinha, tem que ser flecha de índio Atroari, um índio Atroari, ${ }^{9}$ a gente tem que ser uma gilete, um urubu, a gente tem que ser um punhado de coisas" (Drummond, I975: 4).

O autor de livro em vias de ser best-seller, de ser pop, se deixa seduzir pelas múltiplas luzes ofuscantes que lhe são oferecidas de graça pelo presente e as repassa, a preço de algumas e muitas moedas, ao leitor. 


\section{O PARADIGMA DA AUTOAJUDA: A FABRICAÇÃO DO ELIXIR DA LONGA VIDA}

A simples ideia de transformar metais em ouro, ou de descobrir o
Elixir da Longa Vida, já era fascinante demais para passar
despercebida a qualquer iniciante em Magia. Confesso que o
Elixir da Longa Vida me seduzia mais: antes de entender e
sentir a presença de Deus, a ideia de que tudo ia acabar um dia
era desesperadora. De maneira que, ao saber da possibilidade
de conseguir um líquido capaz de prolongar por muitos anos minha
existência, resolvi dedicar-me de corpo e alma à sua fabricação
(Paulo Coelho, o Alquimista, destaque meu).

Retomo a nota de suspense hitchcockiano para avançar o raciocínio geral a um segundo patamar. Pelas metáforas do "cigarro" e da "aspirina" a recobrir a experiência da leitura e pela função delegada ao autor de "amparo" ao leitor na discussão política, já se percebe como o paradigma literário/pop, inaugurado pelo contista Roberto Drummond ao anunciar a época do best-seller, vai transpor o ano-chave de I975 e avançar com galhardia aos últimos anos da década de I980, quando será entregue a Paulo Coelho, o antigo parceiro de Raul Seixas. Ele o redefinirá segundo os ensinamentos dados ao iniciante em Magia. O best-seller ganha nova feição, é nostálgico dos áureos tempos (assim como o presidente eleito nos Estados Unidos da América). E nova forma de atuação, diante da inevitabilidade da doença e da morte, é tão revigorante quanto o elixir de inhame ou o Vinho Reconstituinte Silva Araújo. Tão fantástico quanto as pílulas de vida do Dr. Ross ou aquela pomada anunciada na Praça Sete, que cura cravo e calos.

Enquanto isso, no solo brasileiro que se quer e se diz democrático já pipocam os novos movimentos de resistência política que discutem a formação do Brasil pelo viés dos combativos e variados grupos minoritários. A tensão e a dor-de-cabeça do índio Atroari, lembradas por Roberto em tempos de luta contra a ditadura militar, não são mais causadas só pela invasão das suas terras e pelas hidrelétricas, mas também pela busca da identidade que lhes é a própria, uma identidade entre muitas outras e diferentes que precisam ser recuperadas e afirmadas ou reafirmadas no final do século para que todo brasileiro e toda brasileira cheguem à cidadania plena.

O best-seller de Paulo Coelho cata as migalhas que vinham sendo atiradas ao grande público alfabetizado no esforço de transformar a leitura em experiência comportamental e política acessível a todo alfabetizado. O cigarro, que causa prazer, e a aspirina, que traz o alívio, são ambos venenos a ser evitados pelos corpos e mentes saudáveis. Prazer e alívio da dor ganham conteúdo em novas tramas e em nova linguagem, cuja finalidade óbvia é a autoajuda física e psicológica ao leitor ou à leitora egoístas o suficiente para só se interessar pelos próprios problemas. Trama e linguagem do livro pop, do best-seller, para ser preciso, se travestem da roupagem de uma estória mística ou mágica que, ao se livrar 
das saliências ainda e sempre violentas, injustas e obscuras da nacionalidade brasileira ou da cena internacional, se expressam pela nostalgia dos velhos, misteriosos e felizes tempos da alquimia.

Naqueles tempos, a humanidade era menos fragmentada geográfica e culturalmente e mais segregada e coerente porque centrada na expressão histórica de sua ainda inquestionada e inquestionável fé na universalidade do Ocidente. Imitemos o modelo dos sempre eternos alquimistas, dos sempre eternos segregacionistas. O best-seller vira nicho das relíquias (o que resta do corpo dos santos, sentido cristão da palavra). Somos peregrinos a refazer os caminhos que levam a Santiago de Compostela, onde se encontra o túmulo do apóstolo Tiago. Afirma Paulo Coelho: "o extraordinário reside no caminho das pessoas comuns". A trama e a linguagem indiferenciadas e nostálgicas do best-seller coincidem com a indiferenciada e saudosa governabilidade colonial do mundo civilizado que as várias e distintas nações do Primeiro Mundo voltam a almejar para aplacar as muitas lutas intestinas que afligem o cidadão nos quatro cantos do mundo.

Ao ganhar nova e excêntrica roupagem, a do Elixir da Longa Vida, o bestseller de Paulo Coelho visa ganhar o público alfabetizado de toda e qualquer nação do planeta e, ao assumir a condição de Aleph, passa a ser, segundo as palavras do mago, "um ponto que contém todo o espaço e todo o tempo". Paulo Coelho é de longe o autor mais traduzido da língua portuguesa e por isso é um dos escritores mais lidos no mundo. Leiamos estas suas palavras como metáfora para a fabricação do best-seller de autoajuda: "[...] ao saber da possibilidade de conseguir um líquido capaz de prolongar por muitos anos minha existência, resolvi dedicarme de corpo e alma à sua fabricação" (Coelho, I988: 7). O paradigma pop perde a ambiguidade inicial emprestada por Roberto Drummond em tempos ditatoriais para se transformar em líquido mágico, espécie de Elixir da Longa Vida a ser descoberto e vendido pelo mago, e a ser consumido por todos, indiferentemente.

Autor, livro, leitor, nação e mundo são uniformes. A tautologia ganha o grau supremo de palavra bíblica.

Em oposição ao dizer premonitório de Joaquim Pedro de Andrade durante a ditadura, "Cada um por si e Deus contra todos", agora o individualismo de Paulo Coelho desarma Deus e o apresenta sob a luz otimista da figura todopoderosa do alquimista, espécie antiga do moderníssimo empreendedor neoliberal, capaz de "transformar metais em ouro". A citação metafórica sobre a fabricação do Elixir foi retirada do "Prefácio" a O alquimista, e esta outra, também metafórica sobre o sucesso a ser alcançado pelo autor e qualquer leitor ou leitora do best-seller, é retirada do "Epílogo":

O rapaz sorriu e continuou a cavar. Meia hora depois, a pá bateu em algo sólido. Uma hora depois ele tinha diante de si um baú cheio de velhas moedas de ouro espanholas. Havia também pedrarias, máscaras de ouro com penas brancas e vermelhas. [...] "Realmente a vida é generosa com quem vive sua Lenda Pessoal" (Coelho, I988: 246). 
Cada um por si, com sua lenda pessoal ou o seu curriculum vitae resumido, e o alquimista a ajudar cada um e todos os que são empreendedores em causa própria, na tarefa de descobrir o "tesouro" indiferenciado da identidade abastada, nostálgica e feliz. Os áureos e bons velhos tempos novos.

Graças aos tons nostálgicos da trama e à linguagem passível de ser universalizada, abolem-se as questões que são debatidas e levadas à rua - refirome agora em especial ao Brasil - pelos movimentos minoritários de resistência política, destituindo de peso as várias formas de diferença cidadã que são perseguidas de maneira violenta e incansável pela disseminação no tecido social como um todo das várias práticas cotidianas que o preconceito assume. Nosso país atravessa um período histórico obscuro, violento e trágico, e são as fortes e sedutoras luzes, não mais as da atualidade, mas as do facho de luz nostálgico da alquimia, da magia, dos elixires da longa vida, que iluminam pelo mistério da conquista da riqueza e da fama o rosto do autor e do seu leitor, cegando-os para a compreensão da contemporaneidade.

Gustavo Bernardo Krause (20Io: s.p.) foi feliz no modo como demonstrou que tão importante quanto a transformação alquímica do metal em ouro é a transformação operada pela mudança no design da capa do livro. Escreve ele: "A questão mais grave, porém, reside justamente na imagem do autor, que se sobrepõe, gigantesca, sobre a sua obra, tanto que normalmente a capa dos livros mostra as letras do nome Paulo Coelho muito maiores do que as do título. [...] o que se vende [...] é a persona do autor. Nesse caso, a persona de um mago tão bem-sucedido que ainda por cima é milionário".

\section{A TENDÊNCIA COMO METÁFORA DO CONSUMO}

Proposto por Roberto Drummond, o paradigma pop é retomado como paradigma de autoajuda por Paulo Coelho, e ambos servem de pano de fundo para fascinante e estranha coincidência ocorrida nos fins do século XX, responsável pelo terceiro paradigma, o do consumo. Neste, o leitor não é mais o de livro, já que a leitura pelas classes populares - que serve de alicerce ao terceiro paradigma - se faz de produtos midiáticos e publicitários que visam mais e mais, pelo recurso à todo-poderosa imagem, aos carentes de educação formal. A ação de consumir extrapola, por sua vez, o mero comércio simbólico dos novos produtos da cultura de massa, já que, em economia neoliberal, ela visa açambarcar a aquisição de todo e qualquer bem material. O mercado editorial apenas anunciou uma tendência que se amplificaria e se tornaria vitoriosa no plano da comunidade como um todo.

Evidentemente, o que significou o amparo político aos jovens na literatura pop e o convite ao devaneio saudável e nostálgico aos emergentes no texto de autoajuda passa a significar a satisfação do anseio tanto de novidade por parte da camada pobre da população quanto de atuação política por parte das classes populares. Cito Néstor García Canclini (I995: 84): "O desejo de possuir 
'o novo' não atua como algo irracional ou independente da cultura coletiva a que se pertence". E ainda: "O gosto dos setores hegemônicos tem esta função de 'funil', a partir do qual vão sendo selecionadas as ofertas exteriores e fornecendo as tensões entre o próprio e o alheio" (60-6I).

No paradigma do consumo não mais estão em jogo as poucas moedas exigidas para a posse individual de livro. Requisita-se, no plano da família ou da comunidade, a abundância de moedas para que o desejo individual dos desprivilegiados, devidamente afunilado pelas classes hegemônicas, se satisfaça segundo os desígnios do Estado-nação. Autor e leitor tradicionais, repito, deixam de ser mediatizados pelo livro pop ou pelo best-seller, e a tríade do consumo passa a exigir uma quarta e poderosa figura, a do governante do Estado-nação a elaborar políticas privadas e públicas indispensáveis a uma sociedade do consumo generosa com todos os seus cidadãos.

Estética pop, mensagem de autoajuda e favorecimento nacional do consumo - ainda que com fontes e finalidades distintas - se sucedem cronologicamente e coincidem no tempo e no espaço do presente, no tempo e no espaço predestinados ao exercício da cidadania em período da história nacional que busca mostrar-se igualitário e democrático.

Os três paradigmas, por se assemelharem por efeito de coincidência à cata da explicação de fenômenos culturais e sociopolíticos sucessivos e paralelos, se justificam pelo mesmo desejo de não ter a moda, ou seja, o anacrônico, como metáfora do contemporâneo. O indivíduo ou a classe social optam por não ser moda, mas por "estar-na-moda", "estar-em-moda". Optam por fincar o pé voluptuosamente no presente. Assim sendo, os três paradigmas oferecem ao autor (refiro-me aos dois primeiros paradigmas) e ao ator/consumidor (refiro-me ao terceiro paradigma) a possibilidade de tirar o melhor partido possível da tendência (a palavra torna-se chave e por isso se metaforiza como expressão do presente - e não do contemporâneo). Sempre se deve tirar o melhor partido de tendência prevalente na produção, comercialização e consumo de bens materiais.

Estar-na-moda, estar-em-moda e seguir-a-tendência são sinônimos e têm duas finalidades precisas: a de o indivíduo, ou a classe social a que pertence, se inserir no mercado de trabalho como empreendedor e a de conceder a ele ou à classe o lucro e a fama que lhes abrem, por sua vez, lugar privilegiado na boa sociedade, a que tradicionalmente não pertencem. Sobe-se um ou mais degraus na escada do sucesso. Curiosamente o nome do consumidor - na sua nova condição de empreendedor - ganha na capa da revista-em-moda as letras garrafais que os autores da literatura pop e de autoajuda assumiram nas respectivas capas de best-seller.

Certo: o paradigma do consumo - polo negativo da moda como metáfora do contemporâneo e polo positivo da tendência como metáfora do presente está latente tanto na lista dos autores de best-sellers quanto no desfile pelo 
tapete vermelho (a não ser confundido com o tempo e o espaço próprios à passarela no desfile de moda) das estrelas, produtores e diretores de Hollywood no dia da entrega do Oscar ou de outros prêmios da indústria cultural. São os heróis da indústria cultural globalizada.

Mas ao emprestar as características gerais do best-seller e do blockbuster à abrangente e delicada questão do consumo como decorrente das políticas públicas e privadas para as classes populares, não busco a certeza; busco abrir dúvidas. Por isso é que estou inserindo o terceiro paradigma sob a aba do conceito de coincidência. Até segunda ordem, apelo à coincidência para que explique ou justifique, em tempos pós-ditatoriais com visada igualitária, a articulação entre ambição cultural e, em economia nacional neoliberal, políticas privadas e públicas do Estado-nação com vistas ao pleno exercício da cidadania. Apelo à coincidência, mas ganho coragem para perguntar se os diferentes atores sociais não estariam sendo simultaneamente submetidos - ao vivenciar as luzes do mesmo tempo histórico, o presente, e se situar no mesmo espaço sociocultural iluminado por spots midiáticos e publicitários, a sociedade de consumo - aos clichês pop e de autoajuda e aos valores da irracionalidade econômica pela crença em soluções nostálgicas e mágicas.

Tomo como exemplo Néstor García Canclini e um dos ensaios, "O consumo serve para pensar", que se encontra na coleção Consumidores e cidadãos: conflitos multiculturais da globalização. Não se questionam a inteligência, a ousadia e a oportunidade da proposta do ensaísta mexicano; podem-se questionar os efeitos dela derivados, ou os sintomas, para ser preciso. Resumidamente, eis a proposta: Canclini pretende afugentar as ilusões niveladoras e abstratas da democracia ocidental e do multiculturalismo bem intencionado e homogeneizador, valendo-se dum volteio teórico audacioso. Aproxima o consumo, deplorado por certo discurso político empenhado como lugar da irracionalidade e da submissão das classes populares, ao exercício da cidadania.

Repito-me: não discuto a inteligência, a ousadia e a oportunidade da proposta, mas ouso questionar problemas de coerência cultural. O primeiro deles está na recorrência ao conceito de híbrido, velho companheiro de luta do ensaísta hispano-americano, para dar conta do que nos parece ser mais um bric-à-brac subjetivo em que objetos e formas próprios do conhecimento alheio tornam-se, por estar-em-moda, tendência e, nessa condição, ganham estatuto de legitimidade cultural sem no entanto oferecer a mínima condição de conhecimento que justifique a coerência indispensável ao bom entendimento do contexto.

Tomo um exemplo a Canclini. Ele é longo, mas se faz necessário para se compreender o que se chamou em crítica de poesia de enumeración caótica. ${ }^{\text {10 }}$ No exemplo fica claro que a absorção do conhecimento, tal qual expressa pelo texto (no sentido amplo do termo) dos produtores de televisão e dos publicitários, é incapaz de oferecer as qualidades indispensáveis à formação da consciência 
de cidadão em tempos igualitários e democráticos. Trata-se de enumeração que recolhe signos soltos e desconjuntados a fim de representar o que seja o novo em termos de presente ou de tendência. Há léxico farto, não há sintaxe:

Sem deixar de estar inscritos na memória nacional, os consumidores populares são capazes de ler as citações de um imaginário multilocalizado que a televisão e a publicidade reúnem: os ídolos do cinema hollywoodiano e da música pop, os logotipos de jeans e cartões de crédito, os heróis do esporte de vários países [...]. Marilyn Monroe e os animais jurássicos, Che Guevara e queda do muro, o refrigerante mais bebido no mundo [...] podem ser citados ou insinuados por qualquer desenhista de publicidade internacional confiando em que sua mensagem terá sentido ainda para aqueles que nunca saíram do seu país (Canclini, 1995: 63).

O segundo exemplo está nesta curta passagem em que se percebe nitidamente como a transformação do artesanato popular em best-seller cultural depende de um movimento em que a esperteza do artista/consumidor toma o leme para - como no caso da literatura pop ou do livro de autoajuda - fornecer ao comprador estrangeiro aquilo mesmo que ele deseja. Cito Canclini: "a mistura de ingredientes de origem 'autóctone' e 'estrangeira' é percebida, de forma análoga, no consumo dos setores populares, nos artesãos camponeses que adaptam seus saberes arcaicos para interagir com turistas" (Canclini, I995: 66).

Acredito que o que está em jogo - do ponto de vista da moda como metáfora do contemporâneo - é o que seja a leitura quando a apologia que dela se faz se vale dos signos soltos, disparatados e confusos do presente que, por sua vez, foram os oferecidos à comunidade pelos produtores de televisão e os publicitários. Imagens televisivas e publicitárias são elas as responsáveis, se me concedem a ironia final, de uma espécie de bíblia profana escrita em esperanto e por isso acessível a todos. Esse apagar do livro - não me refiro ao livro literário, como o Grande sertão: veredas, de Guimarães Rosa, mas apenas ao livro pop ou de autoajuda - no raciocínio de Canclini não nos leva a enxergar o facho de trevas que o contemporâneo nos joga no rosto. Prega-se uma leitura que é um prêt-à- porter acessível às classes populares, que redunda em economizar para o Estado-nação a inconveniência de ter de arcar com uma política pública de alto nível em que todos os meninos e todas as meninas possam ser beneficiados indiscriminadamente. Teriam tido acesso a um saber crítico que escapa dos jogos presunçosos e otimistas da tendência. Não é o consumo, é a educação popular, igualitária e democrática que serve para pensar. 
Silviano Santiago é autor de vasta e premiada obra, que inclui romances, contos, poesia, ensaios e crítica. Doutor em letras pela Sorbonne, lecionou em renomadas universidades estrangeiras, na PUC-Rio e é hoje professor emérito da UFF. Entre suas principais obras de crítica, encontra-se Uma literatura nos trópicos (I978), Nas malhas da letra (I989), o cosmopolitismo do pobre (2004) e Genealogia da ferocidade (2017). Publicou recentemente os romances Mil rosas roubadas (Prêmio Oceanos 20I5) e Machado (20I6). 


\section{NOTAS}

I Os sucessivos romances de Horatio Alger (I832-I899) não oferecem mais o modelo para o personagem-em-moda: histórias de pobres que se tornam ricos (em Ragged to riches stories). O vocábulo-em-moda, no Brasil, não é mais self-made man, é entrepreneur, palavra francesa a ser dita em público com ligeiro sotaque anglo-saxão. Ou, no publicitário básico, "empreendedor". Sejam todos.

2 Jerry Rubin, se ainda se lembram do nome, é exemplo precoce de como o narcisismo se cola ao polo negativo da moda ou vice-versa. Na autobiografia Crescendo aos 37 (I976), o anarquista do famoso grupo Chicago 7 escreveu que, de I97I a 1975, tinha experimentado terapia gestalt, bioenergética, comida natural, tai chi, hipnotismo, dança moderna, meditação, acupuntura, terapia sexual etc. Aos 37 anos se sentia como se tivesse 25. Jerry, como outros ex-radicais dos anos I960, conseguia trocar os slogans revolucionários pelos terapêuticos, com igual desrespeito aos dois.

3 "Alto astral / Tudo é lindo / Alto astral / Vivo sorrindo / Alto astral / Ilumine seu cristal". Assista ao videoclipe no link:<https://www.youtube.com/watch?v=W68k UXbKXLA>.

4 O vídeo da personagem da telenovela Alto astral, que foi ao ar na Rede Globo em 20I4, pode ser conferido no link: $<$ https://globoplay.globo.com/v/4I53683/>.

5 É natural que o primeiro elogio do best-seller venha de contista (autor de narrativa curta) que, na verdade, apenas endossa a escrita subjetiva que visa ao sucesso, a do cronista com atividade jornalística. Roberto confessa: "Porque eu sou um cara de formação não literária, entende? Nunca fui de suplemento [literário], eu nunca fui de roda literária, felizmente. O meu exercício [literário] é um exercício feito numa crônica de futebol em jornal mineiro" (Drummond, I975: 3).

6 Os vocábulos "troço" e "negócio" são recorrentes na fala de Roberto Drummond. Deixo a interpretação aos cuidados do leitor.

7 "A vida não me chegava pelos jornais nem pelos livros / Vinha da boca do povo na língua errada do povo / Língua 
certa do povo /Porque ele é que fala gostoso o português do Brasil / Ao passo que nós / O que fazemos / É macaquear / A sintaxe lusíada".

8 Autor de Meu pé de laranja lima (I968), primeiro romance infanto-juvenil pós-I964 de sucesso. A sigla infanto-juvenil é hoje classificada como "young adults", não por acaso dodói do mercado editorial no novo milênio. Lembre-se que, à semelhança de Jorge Amado, o romance de Zé Mauro é best-seller até na França.

9 A partir da ditadura militar, o território demarcado dos índios [Waimiri] Atroari foi invadido por mineradores, grileiros de terra e pelas obras de construção da Usina Hidrelétrica de Balbina. No imaginário da época, eles são conhecidos como guerreiros e resistentes aos desmandos dos militares.

Io Enumeração caótica ou disjecta membra são tópicos estudados por Leo Spitzer (I945) e por Amado Alonso (I940), na América hispânica (Pablo Neruda), e por Marlene de Castro Correia (2009), na literatura brasileira (Carlos Drummond), ao analisar poemas que expressam poeticamente a construção ideologicamente disparatada do presente na poesia contemporânea ou na escrita durante a Segunda Guerra Mundial. Cito Amado Alonso (1940: s.p.): "En sus poemas [de Pablo Neruda] hay manos y pies cortados, trenzas, pelos, uñas, máquinas y parte de máquinas, utensilios sueltos, despojos, tantas y tantas cosas arrancadas de su sitio y navegando a tumbos por este tumultuoso río de versos". Observa Marlene de Castro Correia (2009: 82): "Diversos fatores combinam-se para provocar o desconcerto e o desconforto do leitor: o caráter insólito da imagem, a falta de nexos perceptíveis com o seu contexto, do qual se isola em pequena ilha de ilogicidade". 


\section{REFERÊNCIAS BIBLIOGRÁFICAS}

Agambem, Giorgio. (2009). O que é o contemporâneo? e outros ensaios. Trad. Vinícius Nikastro Honesko. Chapecó: Argos.

Alonso, Amado. (I940). Poesía y estilo de Pablo Neruda. Buenos Aires: Editorial Sudamericana. Disponível em: <http://www. neruda.uchile.cl/critica/capramado.html>. Acesso em 9 fev. 2017.

Canclini, Néstor García. (1995). Consumidores e cidadãos: conflitos multiculturais da globalização. Rio de Janeiro: Ed. UFRJ.

Coelho, Paulo. (I988). O alquimista. Rio de Janeiro: Rocco.

Correia, Marlene de Castro. (2009). Como Drummond constrói "Nosso tempo". Alea: Estudos Neolatinos, II/I, p. 73-86. Disponível em: <https://dx.doi.org/IO.I590/SI5I7-I06X200900 0I00 007>. Acesso em 9 fev. 2017.

Drummond, Roberto. (I975). A morte de D. J. em Paris. Rio de Janeiro: Ática.

Krause, Gustavo Bernardo. (2010). Você também é contra Paulo Coelho? Revista Eletrônica do Vestibular - UERJ, 2/5, Seção Colunas. Disponível em: <http://www.revista.vestibular.uerj. br/coluna/coluna.php?seq_coluna=34>. Acesso em 9 fev. 2017. Spitzer, Leo. (I945). La enumeración caótica en la poesía moderna. Buenos Aires: Facultad de Filosofía y Letras de la Universidad de Buenos Aires/Instituto de Filologia. 


\section{A MODA COMO METÁFORA DO CONTEMPORÂNEO}

Resumo

O artigo parte da definição de Giorgio Agamben da moda como metáfora do contemporâneo. Propõe-se estudar a questão do privado e do público a partir do discurso de best-seller na produção editorial brasileira entre o final do século XX e o começo do XXI. Tal produção é abordada pelo polo negativo em que a metáfora da moda se apresenta, que leva o sujeito a se deixar seduzir pelas luzes do presente, a fim de que se concretize seu desejo individual e intransferível de enriquecimento e de fama. Sucedem-se cronologicamente estética pop, mensagem de autoajuda e favorecimento nacional do consumo. Este último implica uma leitura que é como um prêt-à-porter acessível às classes populares, que faz com que o Estado-nação não precise arcar com uma política pública de alto nível de educação popular igualitária e democrática.

\section{FASHION AS A METAPHOR OF THE CONTEMPORARY}

Abstract

The article sets out from Giorgio Agamben's definition of fashion as a metaphor of the contemporary. It examines the question of the private and the public through the 'best-seller' discourse prevalent in Brazilian publishing between the end of the twentieth century and the start of the twenty-first. This production is explored through the negative sense attributed to the metaphor of fashion, present, convinced that they can realize their individual and non-transferable desire for self-enrichment and fame. In succession we can observe a pop aesthetics, messages of self-help and a nationwide inducement of consumption. The latter involves a reading that functions like a prêt-à-porter accessible to the popular classes, effectively permitting the nation state to eschew any responsibility for developing a high-level public policy for egalitarian and democratic popular education. 